\title{
DEVELOPMENT OF GEOGRAPHIC BOOKLETS LEARNING MEDIA BASED ON ENVIRONMENTAL CARE ON NATURAL RESOURCES MATERIALS IN SENIOR HIGH SCHOOL
}

\author{
Yurdayanti ${ }^{1}$, Nurjanah $^{1}$ \\ ${ }^{1}$ Elementary Teacher Education, FKIP, Universitas Muhammadiyah Bangka Belitung \\ Email: yurdayanti@ stkipmbb.ac.id
}

\begin{abstract}
The character of caring for the environment is essential for students to be wise in protecting natural resources in Indonesia. The planting of environmental care character values can be inserted into the media used in the learning process. This study aims to develop a geography booklet based on environmental concerns related to students' daily experiences. The development model in this study uses the Borg \& Gall stage, which consists of ten development steps. This research was conducted in three senior high schools in Pangkalpinang, Indonesia. There were (100) respondents, all of whom came from eleventh-grade students. The results of the feasibility test of geographic booklet media products based on environmental care characters obtained an average of $93.33 \%$ at the validation stage by a team of experts with very valid criteria. The feasibility of small-scale trials is $83.30 \%$, and large-scale trials are $85.07 \%$. It is known that the results of the analysis of environmental care attitudes obtained before using the product are $63.4 \%$, and after use of $83.8 \%$. It can be indicated that the geography booklet learning media based on environmental care is very feasible to be applied in the classroom and used as a learning resource.
\end{abstract}

Keywords: Environmental Care Character; Geography Booklet; Learning Media.

\section{A. INTRODUCTION}

Geography learning is one of the essential sciences contained in the curriculum in various countries (Arrasyid et al., 2019). The discipline of geography in schools generally teaches spatial-based interactions between humans or between humans and their environment (McPhee, 2021). The world faces environmental degradation problems, including deforestation, biodiversity loss, ocean acidification, ozone depletion, dan water scarcity. Humans are very dependent on their environment, and if damaged, they can no longer support life. Problem solving environmental requires human resources with thoughts, abilities, and skills related to the environment (Rafiei \& Davari, 2015).

The environmental damage that is often reported today is related to geography learning. Studying geography, especially natural resource material, should encourage students to care about their environment. Building the character of a community that cares about the environment allows it to be effective through education in schools (Desfandi, 2015). Caring for the environment is one of the 18 principles to strengthen the implementation of character education 
(Kemdiknas, 2011). It has ingrained character education in students, either directly or indirectly (Jaya et al., 2014). On the other hand, individuality increases among students who do not care about environmental problems. Schools have a special role in helping students understand the impact of human behaviour on the earth where life is sustainable (Ozsoy et al., 2012).

Education is viewed as a lifelong process that civilizes and empowers students. Teachers can provide encouragement in the form of "call to action", thus encouraging students to be aware to be involved in their learning (McPhee, 2021). Teachers can set an example, encourage pupils to participate, and develop their potential and creativity are needed to accomplish this method. Various tactics, such as competency-based education and training approaches, improve schools' quality of learning performance.

Digital pedagogic development in schools is important to pay attention to the complex configuration of storage space, software, algorithms and patterns, standards, protocols, and negotiations (Alirezabeigi et al., 2020). Strategies, facilities, materials, and rationality significantly affect the process of producing learning products (Mangal \& Mangal, 2008). Accessibility and availability of electronic media devices influence teachers in determining their use in learning geography for local studies (Hussaini et al., 2021). A learning media development does not have to follow the latest technological developments, but it is important to emphasize the availability of capital related to technological devices and student characteristics.

Research and development in the use of natural resources that contain the context of local wisdom has been proven to improve students' critical thinking (Gayatri et al., 2018). Learning products that present environmental contexts in concrete forms such as pictures, photos, data, and maps are very meaningful to students (Fatchan et al., 2012). Students consider learning media with real geographic objects to provide benefits when learning.

Purwanto found errors in the organization of the textbooks used by the geography teacher. These errors range from overriding the purpose, inappropriate examples, inappropriate explanations, inadequate explanations, and media content standard errors (Purwanto et al., 2015). Students do not enjoy reading textbooks because the teaching elements are not related to actual events known to students. Products that are not well developed will affect the function of their use so that it allows implementation in 
learning that is also not optimal and even fails. However, it has not been studied further how the development and benefits of textbook media have gone through improvements.

In this study, the booklet learning media was developed by perfecting the concept that contains the context of local wisdom and the context of the surrounding environment. This study aims to develop booklet learning media according to the characteristics of local school students with concepts that touch everyday life. This research is expected to find effective and efficient learning media solutions to build a more active environmental care character and provide something new.

\section{B. MATERIALS AND METHODS}

This study is development research, which develops and validates a product to better suit students' needs. Sugiyono defines development as a process of analysis utilized to create and evaluate certain items (Sugiyono, 2016). Books, modules, and learning tools are examples of products that have been developed, but software such as learning media and learning models can also be used.

This study uses the Borg and Gall stages, which have ten steps that aim to produce a product and test its effectiveness (Gall et al., 2007). This stage is suitable because the stages are more coherent and comprehensive to do. Researchers implemented ten steps consisting of (1) Exploring potential problems,

Gathering information, (3) Product design development, (4) Design validation, (5) Design improvement, (6) Product testing, (7) Revise the test results, (8) Use trials, (9) Revise the final product, (10) Production and distribution of the product. In detail, the stages carried out by the researcher are presented in figure 1.

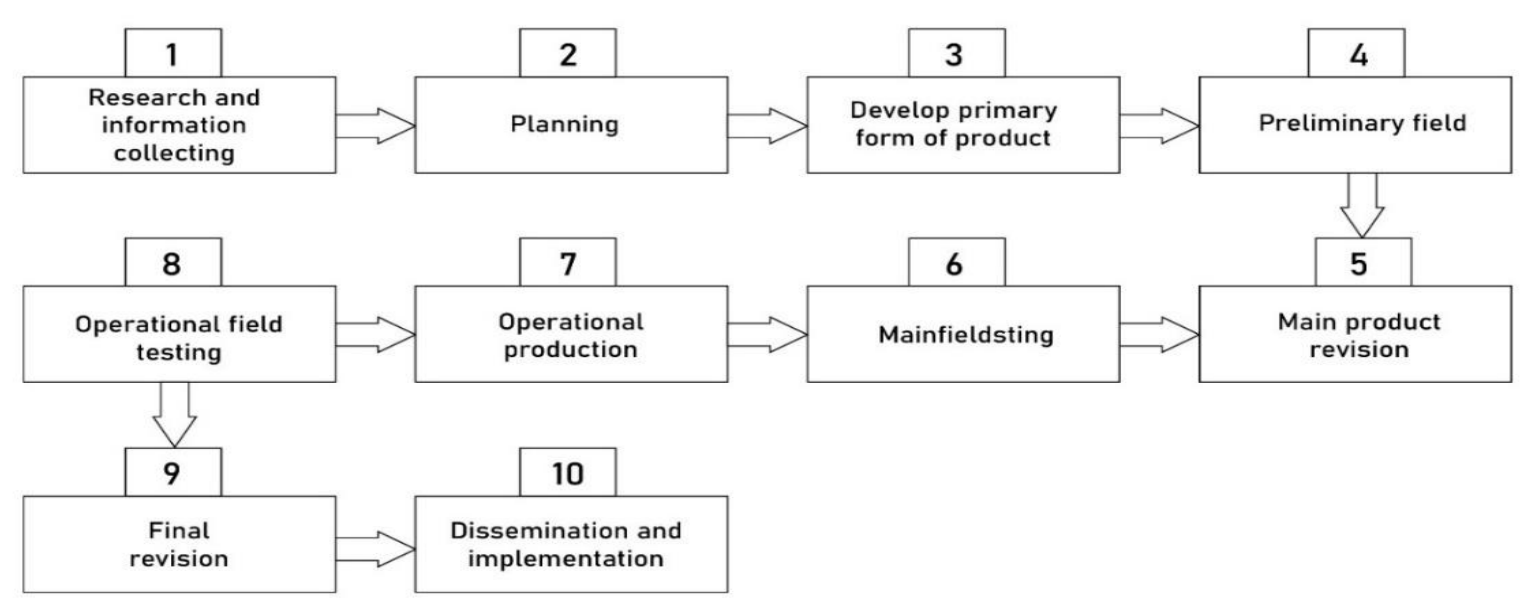

Figure 1. Borg and Gall Development Flow 
This research includes qualitative and quantitative data. The data obtained were in the form of a questionnaire from the research subject, which was then analyzed and calculated to obtain the percentage in this study. Qualitative data was to see the advantages and disadvantages of developing booklet learning media products based on environmental care attitudes.

Data was collected through interviews, questionnaires, observation, and documentation. Interviews were conducted with geography teachers at Pangkalpinang State Senior High School to obtain information about the geography learning process and input related to developing environment-based learning media plans. Questionnaires were given to validators in media, materials, language to assess the product and students to assess the product being tested. Observations were made to determine the current state of the learning process. The documentation used was the school's research profile, a list of student names, syllabus, lesson plans, photos of research activities, and others.

The analytical method used to support the achievement of the objectives of research activities, the methods used were as follows:

1) Research Preparation and Need Analysis Data

This analysis was seen from the needs analysis with interviews with geography teachers and several students to be used to collect information with qualitative descriptive techniques. Needs analysis is used as a basis for the product development of geography booklet media based on environmental care attitude on natural resources materials.

2) Product Development Design

Media design uses flowchart and storyboard basis. Flowcharts show the sequence and relationships between processes, while storyboards show a sketch of each sequence in more detail. The two main foundations in product development are useful for facilitating development from start to finish.

3) Feasibility Data Analysis

The feasibility of learning media for geography booklets based on the attitude of caring for the environment was seen from the content, language, and product appearance by media experts, materials, language, and several students. This assessment was carried out in several stages as follows:

a) Test the validity of the expert team The formula used for the validity of the expert team is:

$\mathrm{NP}=\frac{R}{S M} \times 100$

Information:

$\mathrm{NP}=$ percent value sought or

expected 
$\mathrm{R}=$ raw score of the assessment validator

$\mathrm{SM}=$ ideal maximum score of

statement

$100=$ Fixed number

Table 1. Conversion of Achievement Rate with Scale on Expert Validation Test

\begin{tabular}{|c|c|}
\hline Percentage & Information \\
\hline $0 \%<\mathrm{P} \leq 25 \%$ & Very unvalid \\
\hline $25 \%<\mathrm{P} \leq 50 \%$ & Unvalid \\
\hline $50 \%<\mathrm{P} \leq 75 \%$ & Valid \\
\hline $75 \%<\mathrm{P} \leq 100 \%$ & Very valid \\
\hline
\end{tabular}

was concluded that the product was feasible to use and produced an effective product.

b) Student Assessment Questionnaire Analysis

The test was continued by analysing student assessment questionnaires to see the attractiveness of the booklet with the criteria in table 2 .

Table 2. Conversion of Achievement Rate with Scale

\begin{tabular}{cc}
\hline Criteria & Information \\
\hline Very interesting (SM) & Score 5 \\
\hline Interesting (M) & Score 4 \\
\hline Quite interesting (CM) & Score 3 \\
\hline Less interesting (KM) & Score 2 \\
\hline Very uninteresting (KM) & Score 1 \\
\hline
\end{tabular}

4) Environmental Care Attitude Analysis

To find out the attitude of caring for the environment, it was done by distributing a questionnaire on caring for the environment. This analysis showed whether or not there was an attitude of caring for the environment in class XI IPS students in 3 Senior High Schools in Pangkalpinang by using the percentage formula as follows:

$\mathrm{NP}=\frac{n}{s m} \times 100 \%$

Information :

$\mathrm{NP}=$ Percentage value

$\mathrm{n}=$ Research result/observation

$\mathrm{sm}=$ Maximum score that can be achieved

Table 3. Benchmarks of Percentage Category

\begin{tabular}{|c|c|c|}
\hline Score & $\begin{array}{c}\text { Percentag } \\
\mathrm{e}\end{array}$ & Information \\
\hline $106-140$ & $\begin{array}{l}76 \%- \\
100 \%\end{array}$ & High/good \\
\hline $\begin{array}{l}78- \\
105\end{array}$ & $\begin{array}{c}56 \%- \\
75 \%\end{array}$ & $\begin{array}{c}\text { Moderate/good } \\
\text { enough }\end{array}$ \\
\hline $56-77$ & $\begin{array}{l}40 \%- \\
55 \%\end{array}$ & Low/not good \\
\hline
\end{tabular}
descriptively quantitatively in the form of a frequency table, the target on the aspect of students' environmental care was $>76.00 \%$.

\section{RESULTS AND DISCUSSION}

\section{Potential Problems and Needs} Analysis

This stage was obtained through data collection to explore potentials and problems directly or indirectly by using needs questionnaire analysis and direct interview guidelines to teachers 
and students at Pangkalpinang State High School. According to the findings of the interviews, many students dislike reading textbooks as a critical source of information in class. The teaching elements offered in the textbook were never related to actual objects or events in the real world that students were familiar with, according to the textbook utilized by the teacher in geography learning activities in the classroom. Only a definition of a concept and practice questions were included in the instructional materials. The challenges in the textbook were intellectual in nature as well. The problems presented contain objects and events that were not related to the reality of students. It was the opportunity for researchers to create a media booklet based on caring for the environment. The solution to this problem was to create a booklet based on caring for the environment. Researchers collected relevant information from various sources. The booklet will contain material information about natural resources related to problems in students' daily lives. Learning that emphasizes the context of the environmental crisis encourages the assumption of the importance of preserving the environment by minimizing the consumption of natural resources
(Wibowo et al., 2021). The development step was continued by compiling a booklet design based on environmental care for class XI IPS students at three public high schools in Pangkalpinang.

\section{Development of Geography Booklet} Media based on Environmental Care Attitude on Natural Resources Materials

The design developed, compiled as a geography booklet media based on an attitude of caring for the environment, has its charm, which was packaged in the form of the required booklet media. The attractiveness of the booklet media based on the attitude of caring for the environment was as follows:

a) The beginning and cover of the booklet were designed from a cover, introduction, table of contents, and a sheet that contained various characters, especially the character of caring for the environment accompanied by combining colors, images (illustrations), shapes, and font sizes attract students' attention.

b) The chapter contains learning objectives, concept maps, descriptions of summary material, and formative tests with the 
context of problems in the surrounding environment.

c) The contents contained pictures or illustrations, bold, italics, or colors not found in ordinary books.

d) There was up-to-date information in geography booklet media based on environmental care attitudes linked to character education.

e) Ideal size and easy to carry, good use of paper

f) Assignments and exercises were well packaged to be attractive.

g) The final section is equipped with a glossary, bibliography, and author biodata that allows students to explore other literacy about natural resources and environmental care attitudes.

The design that had been developed was obtained in the form of a booklet learning media based on an attitude of caring for the environment with natural resource materials for students of class XI IPS High School. The following were sections of the geography booklet learning media that have been compiled:

1) Cover: included the title "GEOGRAPHY For High Schools."

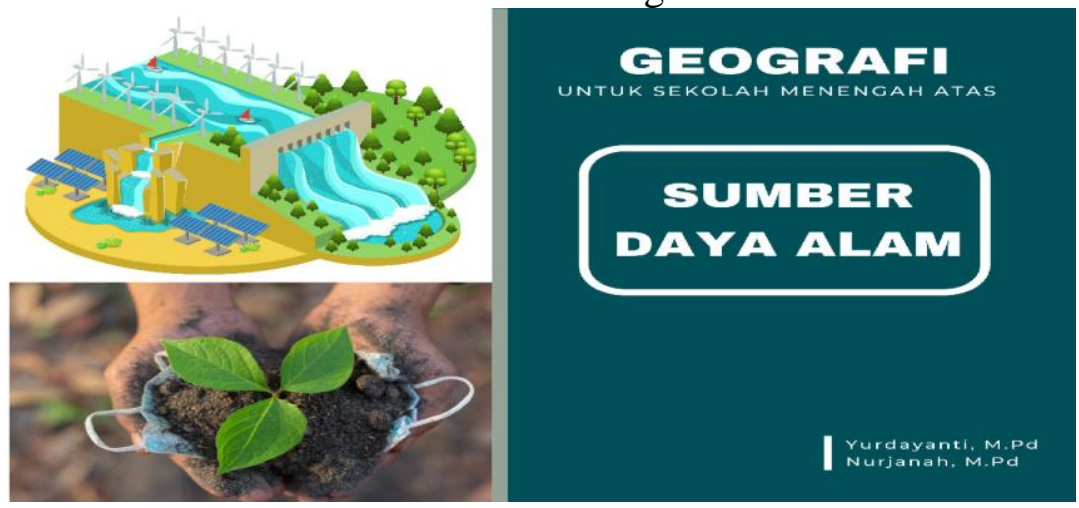

Figure 2. Revised geography booklet media cover 
2) Foreword, compiled containing thanksgiving and a brief description of the geography booklet media, as well as the author's hopes:

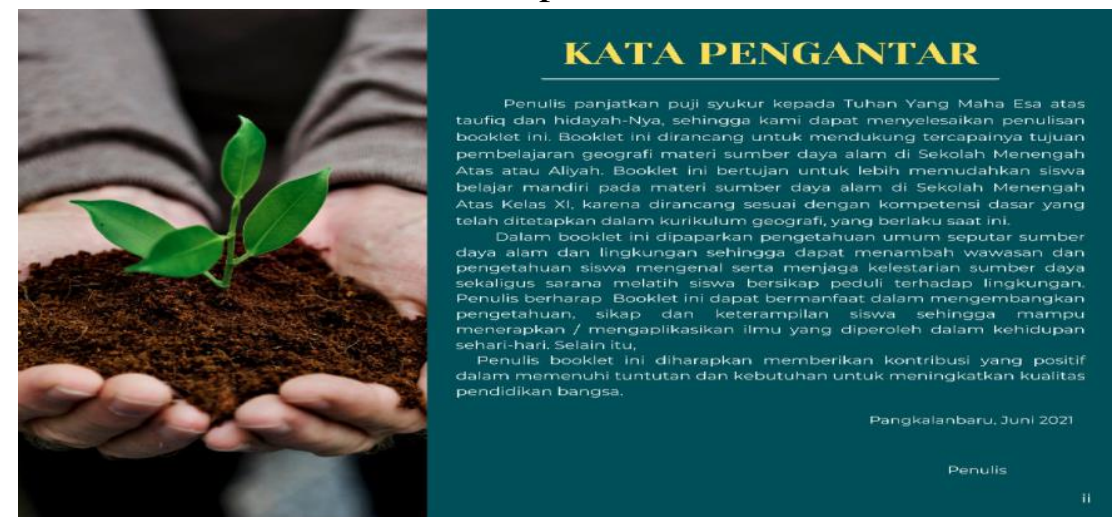

Figure 3. Preface after revision

3) Table of Contents, including outline (outline)

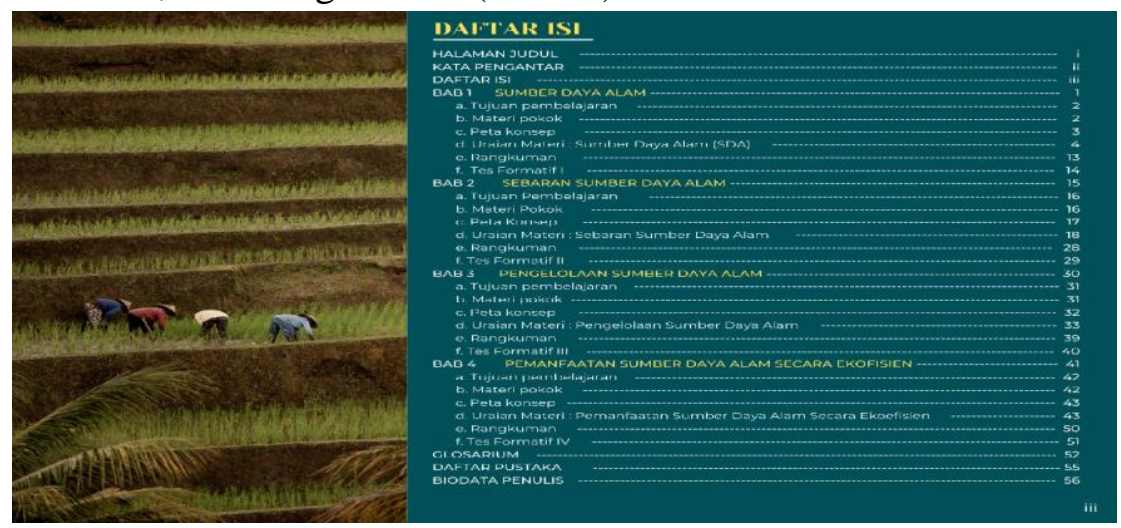

Figure 4. Table of contents after revision

4) The media content section of the booklet included learning objectives, sub materials, concept maps, material descriptions, summaries, per-activity exercises, formative tests.

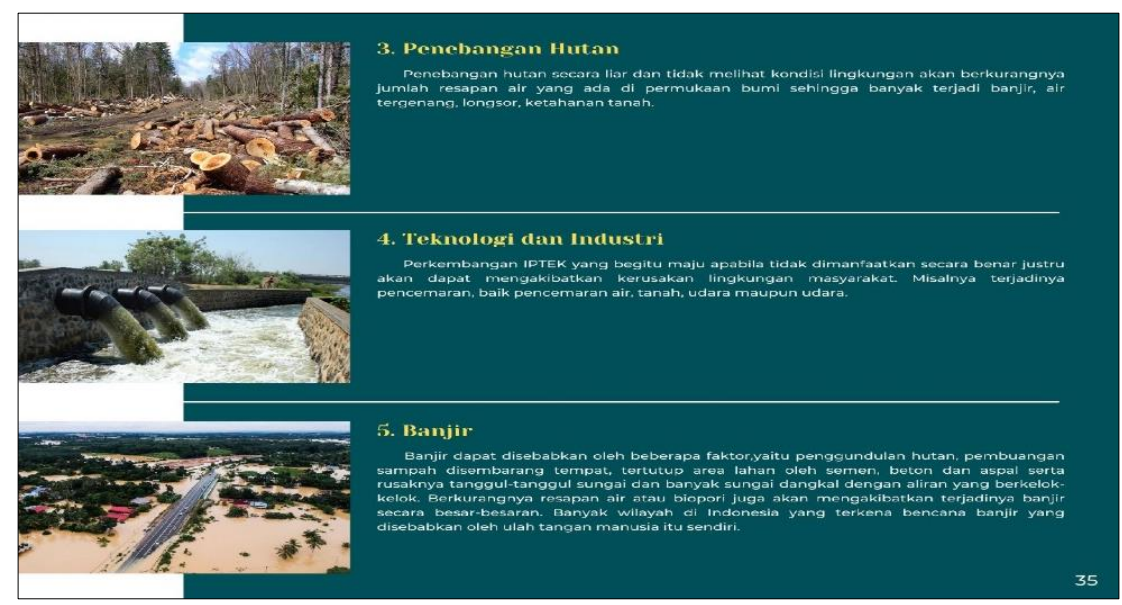

Figure 5. Example of the contents of a booklet showing the damage to the surrounding environment

5) The final part of the media booklet included a bibliography, glossary, and author's bio. 
3. Feasibility of Media Booklet Based on

Environmental Care Attitude

\section{Material Natural Resources}

a) Description of Expert Team Validation

Product validation was carried out using a questionnaire given to validators, media experts, material experts, and linguists to assess the validator. The results of the validation obtained data analysis based on data analysis techniques that had been formulated. The summary of the data from the validation aspects was described as follows:

Table 4. Recapitulation of the Validation Results of Geography Booklet Media Assessment

\begin{tabular}{llcl} 
No. & Assessment Aspect & $\begin{array}{c}\text { Percentage } \\
(\mathbf{\%})\end{array}$ & Category \\
\hline 1 & Material Presentation & $88.33 \%$ & Very Valid \\
\hline 2 & Curriculum & $90.00 \%$ & Very Valid \\
\hline 3 & Learning Evaluation & $93.33 \%$ & Very Valid \\
\hline 4 & Execution & $93.33 \%$ & Very Valid \\
\hline 5 & language & $86.67 \%$ & Very Valid \\
\hline 6 & Sentence Clarity & $93,33 \%$ & Very Valid \\
\hline 7 & Print Quality & $100.00 \%$ & Very Valid \\
\hline 8 & Design Quality & $100.00 \%$ & Valid \\
\hline 9 & Display Quality & $93.33 \%$ & Valid \\
\hline & Average Percentage & $\mathbf{9 3 , 6 6 \%}$ & Very Valid
\end{tabular}

Source: Primary Data Year 2021

The table above showed the assessment results of the assessment booklet by the assessment team regarding the aspect of presenting the material, obtaining a total of $88.33 \%$, which can be categorized as very valid. The results of the booklet assessment on curriculum specs obtained a percentage of $90.00 \%$, which can be classified as very valid. The results of the booklet assessment on the aspects of evaluation and implementation of learning obtained a percentage of $93.33 \%$.

The results of the booklet assessment on the linguistic aspect obtained a percentage of $86.67 \%$, categorized as very valid. In this aspect, it included the choice of words and language according to the EYD. For sentence clarity in this booklet, the percentage obtained was $93.33 \%$, with a very valid category. 
The results of the booklet assessment on aspects of print quality and design obtained a percentage of $100.00 \%$, which included clarity of writing, attractive colors, and provides comfort for readers so that it was categorized as very valid. While the last aspect, namely the aspect of display quality, was obtained as much as $93.33 \%$ with a very valid category.

From the results of the analysis of the validator's assessment, it could be concluded that this geography booklet had been made and requires a minor revision. The criticisms and suggestions from expert validators were as follows:

Table 5. Advice from experts

\begin{tabular}{cll}
\hline No & \multicolumn{1}{c}{ Suggestions/ Comments } & \multicolumn{1}{c}{ Repair } \\
\hline 1 & $\begin{array}{l}\text { The picture needs to be clarified again } \\
\text { because some pictures cannot be seen. }\end{array}$ & $\begin{array}{l}\text { Review images and improve image } \\
\text { quality for more precise viewing. }\end{array}$ \\
\hline 2 & $\begin{array}{l}\text { Correct spelling and sentences with many } \\
\text { letter errors. }\end{array}$ & $\begin{array}{l}\text { Fixed according to validator's } \\
\text { suggestion }\end{array}$ \\
\hline 3 & $\begin{array}{l}\text { Add material in subchapter two regarding } \\
\text { tourism potential }\end{array}$ & Fix according to validator's suggestion \\
\hline 4 & $\begin{array}{l}\text { Refine the questions to an adjusted level } \\
\text { of difficulty }\end{array}$ & $\begin{array}{l}\text { Questions are made based on facts in } \\
\text { everyday life by relating to the concept } \\
\text { of natural resources. }\end{array}$ \\
\hline
\end{tabular}

After getting the percentage results and suggestions from the validator, the next stage was the revision or improvement stage, according to the recommendations from the validator, so that it could become a perfect product that was ready to be tested.

\section{b) Trial Results of Geography Booklet Media by Students}

The geography booklet media trial was conducted to determine the suitability of the developed booklet media. Through this trial, a media booklet based on an attitude of caring for the environment was produced. Students were given a questionnaire to assess the feasibility of the booklet containing questions about the suitability of the material, design, writing, and student motivation.

The results of the limited trial were carried out through several revision stages from the experts, who were then tested in small classes to find out input and suggestions from 10 students randomly to represent the target media for the booklet made. The results of the 
limited trial obtained to obtain the product broadly could be seen in the following table:

Table 6. Percentage of Limited Trial Results on Geography Booklet Media Based on Environmental Care Attitude

\begin{tabular}{clcl}
\hline No & Assessment Aspect & $\begin{array}{c}\text { Percentage } \\
(\mathbf{\%})\end{array}$ & Criteria \\
\hline 1 & Material presentation & 85,33 & very feasible \\
\hline 2 & Study evaluation & 79,00 & very feasible \\
\hline 3 & language & 92,67 & very feasible \\
\hline 4 & Sentence clarity & 81,33 & very feasible \\
\hline 5 & Time Allocation & 86,40 & very feasible \\
\hline 6 & Cover Design Quality & 90,90 & very feasible \\
\hline 7 & Display Quality & 90,90 & very feasible \\
\hline
\end{tabular}

The results obtained were $85.33 \%$ in presenting the material, which was included in the very feasible criteria. This aspect had been fulfilled because the material presented was following facts, theories and did not give rise to new interpretations.

In the aspect of learning evaluation, the percentage of results obtained was $79.00 \%$ in very decent criteria, including learning activities containing material to help students achieve learning objectives following the competencies presented.

The linguistic aspect obtained results of $92.67 \%$ with very feasible criteria, including the language used according to the high school level and using the language according to the EYD. At the same time, the aspect of sentence clarity was obtained at $81.33 \%$, which was very feasible. It was said that the geography booklet media fulfilled every presentation of the material and could balance the learning speed of high school students.

Aspects of time allocation obtained an assessment of $86.40 \%$ "very feasible." Good response to design and display quality was 90.90\% with very decent criteria, design and display presentation with attractive and easy-to-understand images through language and pictures that directed students to understand the material presented. It had received a positive response in terms of design and appearance. The following response was an 
evaluation of the questionnaire from the students, and then from the limited-scale trial, a revision was made to apply it to students. The questionnaire evaluation from the limited-scale trial was used to make revisions before being applied to the next trial.

Furthermore, external scale trials were carried out on students of class XI IPS in 3 Senior High Schools in Pangkalpinang with 100 students. All students were given a revised draft of the geography booklet based on the validation and limited trial results. In the largescale trial, students were given a different questionnaire from the small-scale trial stage. The questionnaire was used to determine the attitude of environmental stewardship by delivering an environmental stewardship questionnaire.

\section{The results of the Environmental Care Attitude Questionnaire for Class XI Social Sciences SMA Negeri Pangkalpinang.}

From the results of the questionnaire analysis of environmental care attitudes, it could be seen in the table below:

Table 7. Results of the Environmental Care Attitude Questionnaire Recapitulation Learning Media Booklet Based on Environmental Care Attitude

\begin{tabular}{ccccc}
\hline No & Score & \multicolumn{2}{c}{ Frequency } & Information \\
\hline 1 & $106-140$ & 80 students & $80 \%$ & High/good \\
\hline 2 & $78-105$ & 15 students & $15 \%$ & Moderate/enough \\
\hline 3 & $56-77$ & 5 students & $5 \%$ & Low/less \\
\hline 4 & Amount & 5 students & $100 \%$ & \\
\hline
\end{tabular}

From the results of the environmental care attitude questionnaire analysis, it was found that there were still five students who were in the score range of 56-77. It meant that they were in the low/less category with a percentage of $5 \%$. Fifteen students were in the range of 78-105 with a percentage of $15 \%$, and 80 students were in the score range of 106-104. It is in the high/good category with a percentage of $80 \%$. It meant that the geography booklet media based on caring for the environment is said to be high/good at 
caring for the environment. The attitude of caring for the environment is considered to have been embedded in each student's character. This good character is expected to encourage students to preserve their environment.

\section{CONCLUSIONS}

It is known that previously students were not interested in reading booklets as the primary material because they contained objects and events that were not related to students' reality. Researchers developed a geography booklet by making improvements based on known deficiencies. Geography booklets learning media are developed systematically according to the stages in the development model. The media went through a validation test phase from media, material, and language experts, which showed that the media was very valid. Tests conducted on students showed the results of the criteria were very feasible. The analysis results of students' environmental care attitudes have increased with the acquisition of a high/good category. Students are interested in studying the material in the booklet that was developed during the learning process because it contains the context of environmental problems around them. Students consider through the concept of learning with the help of this media it can make it easier for them to understand the learning material. Giving examples of actual concepts and practices in the surrounding environment by adjusting the characteristics of students is proven to make the material easier for students to understand (Kamil et al., 2020; Rickles et al., 2017). Teachers can increase students' environmental awareness by setting an example to students through good deeds towards the environment in their daily routines (Norsidi \& Sariani, 2021). In addition to the context of learning, the attitude of caring for the environment that grows in students has begun to appear to be implemented in everyday life towards the surrounding environment.

\section{E. ACKNOWLEDGMENTS}

Thank you to the Institute of the Ministry of Research and Technology in research for funding the sustainability of this journal.

\section{F. REFERENCES}

Alirezabeigi, S., Masschelein, J., \& Decuypere, M. (2020). Investigating digital doings through breakdowns: a sociomaterial ethnography of a Bring Your Own Device school. Learning, Media and Technology, 45(2), 193-207. https://doi.org/10.1080/17439884.2 020.1727501

Arrasyid, R., Setiawan, I., \& Sugandi, D. (2019). Developing Learning Media Based on Geographic Information 
System for Geography Subject in Senior High Schools. Jurnal Pendidikan Ilmu Sosial, 28(1), 1. https://doi.org/10.17509/jpis.v28i1. 12163

Desfandi, M. (2015). Mewujudkan Masyarakat Berkarakter Peduli Lingkungan Melalui Program Adiwiyata. SOSIO DIDAKTIKA: Social Science Education Journal, 2(1), 31-37. https://doi.org/10.15408/sd.v2i1.166 1

Fatchan, A., Amirudin, A., \& Utaya, S. (2012). Effect of Learning Task Group Based on Field Survey (Outdoor Study) for Scientific Writing Ability and Student Results. Journal of Education, 18-35.

Gall, M., Gall, J., \& Borg, W. (2007). Educational Research: An Introduction, Seventh Edition (p. 656). Longman.

Gayatri, T., Soegiyanto, H., \& Rintayati, P. (2018). Development of Contextual Teaching Learning-Based Audio Visual Adobe Flash Media to Improve Critical Thinking Ability of Geography Learning at Senior High School. IOP Conference Series: Earth and Environmental Science, 145(1).

https://doi.org/10.1088/1755-

1315/145/1/012004

Hussaini, Y. J., Maxwell, A. F., \& Zagi, D. J. (2021). Accessibility of Electronic Media for Learning Geography in a College of Education in Bauchi State , Nigeria. 7(4), 1-10.

Jaya, I. M., Sadia, I. W., \& Arnyana, I. B. P. (2014). Pengembangan Perangkat Pembelajaran Biologi Bermuatan Pendidikan Karakter Dengan Setting Guided Inquiry Untuk Meningkatkan Karakter dan Hasil Belajar Siswa SMP. E-Journal Program Pascasarjana Universitas
Pendidikan Ganesha Program Studi IPA, 4, 1-12.

Kamil, P. A., Utaya, S., Sumarmi, \& Utomo, D. H. (2020). Improving disaster knowledge within high school students through geographic literacy. International Journal of Disaster Risk Reduction, 43(November 2019), 101411. https://doi.org/10.1016/j.ijdrr.2019. 101411

Kemdiknas. (2011). Panduan Pelaksanaan Pendidikan Karakter. Kementerian Pendidikan Nasional.

Mangal, S. K., \& Mangal, U. (2008). Essentials of Educational Technology. PHI Learning Private Limited.

McPhee, S. R. (2021). Advocating for blended pedagogy as a shift to more holistic inclusive geography. Journal of Geography in Higher Education, $\quad 00(00), \quad 1-12$. https://doi.org/10.1080/03098265.2 021.1957802

Norsidi, N., \& Sariani, N. (2021). Implementation of Character Education Towards a School of Culture and Environmental Care (ADIWIYATA). GeoEco, 8(1), 2534.

Ozsoy, S., Ertepinar, H., \& Saglam, N. (2012). Can eco-schools improve elementary school students' environmental literacy levels? AsiaPacific Forum on Science Learning and Teaching, 13(2), 1-25.

Purwanto, E., Fatchan, A., -, P., \& Soekamto, H. (2015). Development of Geography Text Books Used by Senior High School Teachers Case Study at East Java-Indonesia. Journal of Education and Learning, 5(1), 60. https://doi.org/10.5539/jel.v5n1p60

Rafiei, N., \& Davari, F. (2015). The Role of Human Resources Management 
on Enhancing the Teaching Skills of Faculty Members. Materia Socio Medica, 27(1), 35. https://doi.org/10.5455/msm.2014.2 7.35-38

Rickles, P., Ellul, C., \& Haklay, M. (2017). A suggested framework and guidelines for learning GIS in interdisciplinary research. Geo: Geography and Environment, 4(2). https://doi.org/10.1002/geo2.46

Sugiyono. (2016). Metode Penelitian Kuantitatif, Kualitatif dan $R \& D$. Alfabeta.

Wibowo, N. A., Sarwono, S., \& Yusup, Y. (2021). Environmental Care Attitude of the Students in Senior High School at Pati Regency. GeoEco, 7(2). 